\title{
AZ EGÉSZSÉGÜGYI SZOLGÁLTATÓK CSŐDMODELLVIZSGÁLATA
}

\author{
Hegedűs Mihály
}

\section{Összefoglalás}

Az elemzés tárgyát képezó intézmény a Péterfy Kórbáz-Rendelöintézet és Manninger Jenö Országos Traumatológiai Intézet. Azért erre a kórbázra esett a válasżtás, hogy a belyzete elemzés-re kerüljön, mert korábban készitettem róla egy csödmodell vizsgálattal egybekötött tanulmányt. A korábbi adatokból felállitott elörejelzéseke, követkeațetések bekövetkezését is tudom vizsgálni azáltal, hogy a korábbi kutatást folytatom, illetve igy nagyobb idôszakot tud felölelni a mostani analiris, igy még pontosabb kép kapható a jövöre nézve az intézmény tekintetében.

A mérleg adatok vizsgálata a 2014-2019. évek adataival zajlik, ennek az oka, hogy a 2014. évben változott a költségvetési beszámoló formátuma, sorai, igy a beszámolók a korábbi évek-kel való összehasonlitása átalakitással lenne lehetséges, viszont a terjedelmi korlátok miatt jelen tanulmányban, eat nem valósitom meg. A csödmodell vizsgálat azonban a 2006. évtöl vizsgálja az intézményt, hiszen a mutatók a megfelelö kikötésekekel a korábbi beszámoló séma szerint is számithatóak.

Az eszközöö és források elemzése során csak azok a mérlegsorok kerülnek bemutatásra, amelyek a vizsgált idöszak vonatkozásában értékkel birnak.

Kulcsszavak: csöd, csödmodell, likviditás

JEL: G33

\section{BANKRUPTCY MODEL EXAMINATION OF HEALTH CARE PROVIDERS}

\begin{abstract}
The institution that is the subject of the analysis is the Péterfy Hospital-Clinic and Jenö Manninger National Institute of Traumatology. This hospital was chosen to have its situation ana-lyzed, because I had previously done a study on it in conjunction with a bankruptcy model study. I can also examine the occurrence of forecasts and conclusions from previous data by continuing the previous research, and thus the current analysis can cover a longer period, so an even more accurate picture can be obtained for the future of the institution.

The examination of the balance sheet data is carried out with the data of the years 2014-2019, the reason for this is that the format and lines of the annual report has changed in 2014, so the comparison of the reports with previous years could be possible by transformation, however, due to size limitations in the present study I do not implement this. The bankruptcy model study bas been examining the institution since 2006, as the indicators can also be calculated according to the previous reporting scheme with the appropriate stipulations.

In the analysis of assets and liabilities, only those balance sheet lines are presented that have value for the period under review.
\end{abstract}

Keywords: bankruptcy, bankruptcy model, liquidity

JEL: $G 33$ 


\section{Bevezetés}

Az egészségügyi szolgáltatók csődmodell vizsgálata során egy konkrét kórház alapos elemzését vittem véghez. Az elemzés tárgyát képező intézmény a Péterfy Kórház-Rendelőintézet és Manninger Jenő Országos Traumatológiai Intézet. Azért erre a kórházra esett a választás, hogy a helyzete elemzésre kerüljön, mert korábban készítettem róla egy csődmodell vizsgálattal egybekötött tanulmányt. A korábbi adatokból felállított előrejelzések, következtetések bekövetkezését is tudom vizsgálni az által, hogy a korábbi kutatást folytatom, illetve így nagyobb időszakot tud felölelni a mostani analízis, így még pontosabb kép kapható a jövőre nézve az intézmény tekintetében.

A mérleg adatok vizsgálata a 2014-2019. évek adataival zajlik, ennek az oka, hogy a 2014. évben változott a költségvetési beszámoló formátuma, sorai, így a beszámolók a korábbi évekkel való összehasonlítása átalakítással lenne lehetséges, viszont a terjedelmi korlátok miatt jelen tanulmányban, ezt nem valósítom meg. A csődmodell vizsgálat azonban a 2006. évtől vizsgálja az intézményt, hiszen a mutatók a megfelelő kikötésekkel a korábbi beszámoló séma szerint is számíthatóak.

Az eszközök és források elemzése során csak azok a mérlegsorok kerülnek bemutatásra, amelyek a vizsgált időszak vonatkozásában értékkel bírnak.

\section{Anyag és módszer}

Jelen publikáció terjedelmi korlátok miatt csak részadatokat, a kutatás egy-egy szegmensét emeli ki, azonban ezek a részadatok önállóan is értelmezhetőek, az egyes összefüggések a részelemek tekintetében is vizsgálhatóak.

A tanulmány fel kívánja hívni a figyelmet az egészségügyi szektor problémáira és arra is, hogy a statisztikai adatok, illetve a sajtóértesülésekből levonható következtetések jelentôs mértékben távol esnek egymástól.

A csőd esélye az egészségügyi szektorra konstans veszélyt jelent. Az elemzés nem érin-ti a téma teljes körű elemzését, az összegzés fejezet azonban az összefüggések miatt számos területre vonatkoztatható következtetéseket, javaslatokat fogalmaz meg.

A jelen elemzés feladata és célkitűzése a figyelemfelhívása azzal kapcsolatban, hogy mindennapjaink része az egészségügyi szektor, mindenkinek tudnia kell róla és a benne rejlő veszélyekről.

A jelen publikáció az egészségügyi szektor adatainak feldolgozásán, valamint korábbi kutatásaim eredményén, tapasztalataimon alapul, illetve kérdőíves felmérést, valamint interjút alkalmaztunk.

A kutatás célja, hogy pontos képet adjon az egészségügyi szektor helyzetéről és a lehetséges csődveszélyről.

\section{Eredmények}

A Péterfy Kórház-Rendelőintézet és Manninger Jenő Országos Traumatológiai Intézet adatai kerültek elemzésre. 


\section{1. táblázat. A Péterfy Kórház-Rendelőintézet és Manninger Jenő Országos}

Traumatológiai Intézet eszközeinek összehasonlítása

\begin{tabular}{|c|c|c|c|c|c|c|}
\hline Megnevezés & 2014 & 2015 & 2016 & 2017 & 2018 & 2019 \\
\hline A/I Immateriális javak & 9028 & 2853 & 542 & - & - & 8095 \\
\hline A/II Tárgyi eszközök & 7211012 & 7320836 & 7192996 & 7374403 & 7551469 & 7662710 \\
\hline $\begin{array}{l}\text { A) NEMZETI VAGYONBA TAR- } \\
\text { TOZÓ BEFEKTETETT ESZKÖ- } \\
\text { ZÖK }\end{array}$ & 7220040 & 7323689 & 7193538 & 7374403 & 7551469 & 7670805 \\
\hline B/I Készletek & 217606 & 233411 & 231269 & 260057 & 221930 & 219967 \\
\hline $\begin{array}{l}\text { B) NEMZETI VAGYONBA TAR- } \\
\text { TOZÓ FORGÓESZKÖZÖK }\end{array}$ & 217606 & 233411 & 231269 & 260057 & 221930 & 219967 \\
\hline $\begin{array}{l}\text { C/II Pénztárak, csekkek, betétköny- } \\
\text { vek }\end{array}$ & - & 1098 & 1077 & 929 & 1573 & 1061 \\
\hline C/III Forintszámlák & 318445 & 307381 & 852764 & 573362 & 449926 & 851927 \\
\hline C) PÉNZESZKÖZÖK & 318445 & 308479 & 853841 & 574290 & 451499 & 852988 \\
\hline $\begin{array}{l}\text { D/I Költségvetési évben esedékes } \\
\text { követelések }\end{array}$ & 122050 & 91951 & 105932 & 118154 & 1463360 & 1607662 \\
\hline $\begin{array}{l}\text { D/II Költségvetési évet követően } \\
\text { esedékes követelések }\end{array}$ & 90219 & 1998660 & 2198286 & 2562217 & 1296965 & 1398598 \\
\hline $\begin{array}{l}\text { D/III Követelés jellegű sajátos el- } \\
\text { számolások }\end{array}$ & 150 & 36 & - & 6795 & 89 & 65784 \\
\hline D) KÖVETELÉSEK & 212419 & 2090647 & 2304218 & 2687166 & 2760414 & 3072045 \\
\hline $\begin{array}{l}\text { E/I Elözetesen felszámított általá- } \\
\text { nos forgalmi adó elszámolása }\end{array}$ & - & - & 655 & 2177 & 109 & 17750 \\
\hline $\begin{array}{l}\text { E/II Fizetendő általános forgalmi } \\
\text { adó elszámolása }\end{array}$ & - & - & -2750 & -882 & -603 & -3085 \\
\hline $\begin{array}{l}\text { E/III Egyéb sajátos eszközoldali el- } \\
\text { számolások }\end{array}$ & 377477 & 364403 & 41614 & 18673 & 27009 & 4570 \\
\hline $\begin{array}{l}\text { E) EGYÉB SAJÁTOS ELSZÁMO- } \\
\text { LÁSOK }\end{array}$ & 377477 & 364403 & 39519 & 19969 & 26516 & 19236 \\
\hline $\begin{array}{l}\text { F) AKTÍV } \\
\text { IDÖBELIELHATÁROLÁSOK }\end{array}$ & 1957450 & - & - & 4532 & 5349 & - \\
\hline ESZKÖZÖK ÖSSZESEN & 10303437 & 10320629 & 10622385 & 10920418 & 11017177 & 11835042 \\
\hline
\end{tabular}

\section{A mérlegben szereplö eszközök elemzése}

A vagyon értéke 2014. évben 10303437 E Ft volt, mely 2015. évre 10320629 E Ft-ra, 2016-ban 10622385 E Ft-ra változott, majd 2017. évre 10920418 E Ft-ra növekedett, majd 2018. évre tovább növekedett és 11017177 E Ft volt. A vagyon értéke 2019-ben 11835042 E Ft.

A 2018. évhez viszonyított változáshoz 2019. évre eszközoldalon elsődlegesen a pénz-eszközök 401489 E Ft-os (88,92\%), a követelések 311631 E Ft-os (11,29\%) és a befektetett eszközök állományának 119336 E Ft-os (1,58\%) növekedése járult hozzá.

A növekedést ellensúlyozta az egyéb sajátos eszközoldali elszámolások 27,45\%-os, $7280 \mathrm{E} \mathrm{Ft}$ összegű csökkenése, illetve az aktív idôbeli elhatárolások 100\%-os, 5349 E Ft összegű csökkenése, valamint a forgóeszközök 1963 E Ft-tal (0,88\%) történő csökkenése.

Az egyéb sajátos elszámolások, illetve a követelések változása kellő korrekcióval hasonlitható össze az évenként eltérő tartalom miatt.

Az Intézmény nemzeti vagyonba tartozó befektetett eszközeinek aránya (2014-ben 70,07\%) az összes eszközhöz viszonyítva 2015-re 70,96\%-ra változott, míg 2016. évre 7193538 E Ft-ra, 67,72\%-ra csökkent. 2017. évben a befektetett eszközök aránya az összes eszközhöz viszonyítva 67,53\% volt, amely a 2018. évre 68,54\%-ra emelkedett. 2019. évben az arányszám 64,81\%-os értékkel bírt. 


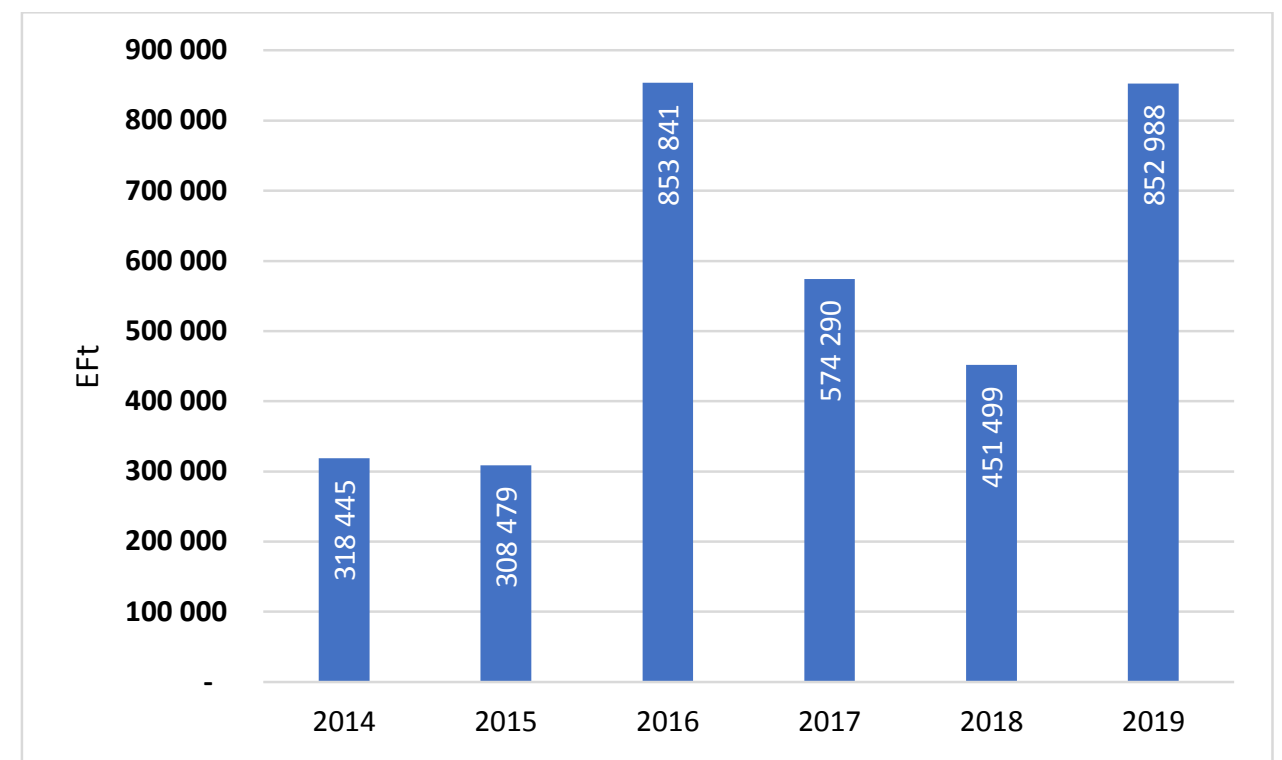

\section{1. ábra. Péterfy Sándor utcai Kórház-Rendelőintézet és Baleseti Központ pénzeszközeinek alakulása}

A pénzeszközök záró állománya hektikusan mozog, mint ahogy az az 1. számú ábrán is látszik.

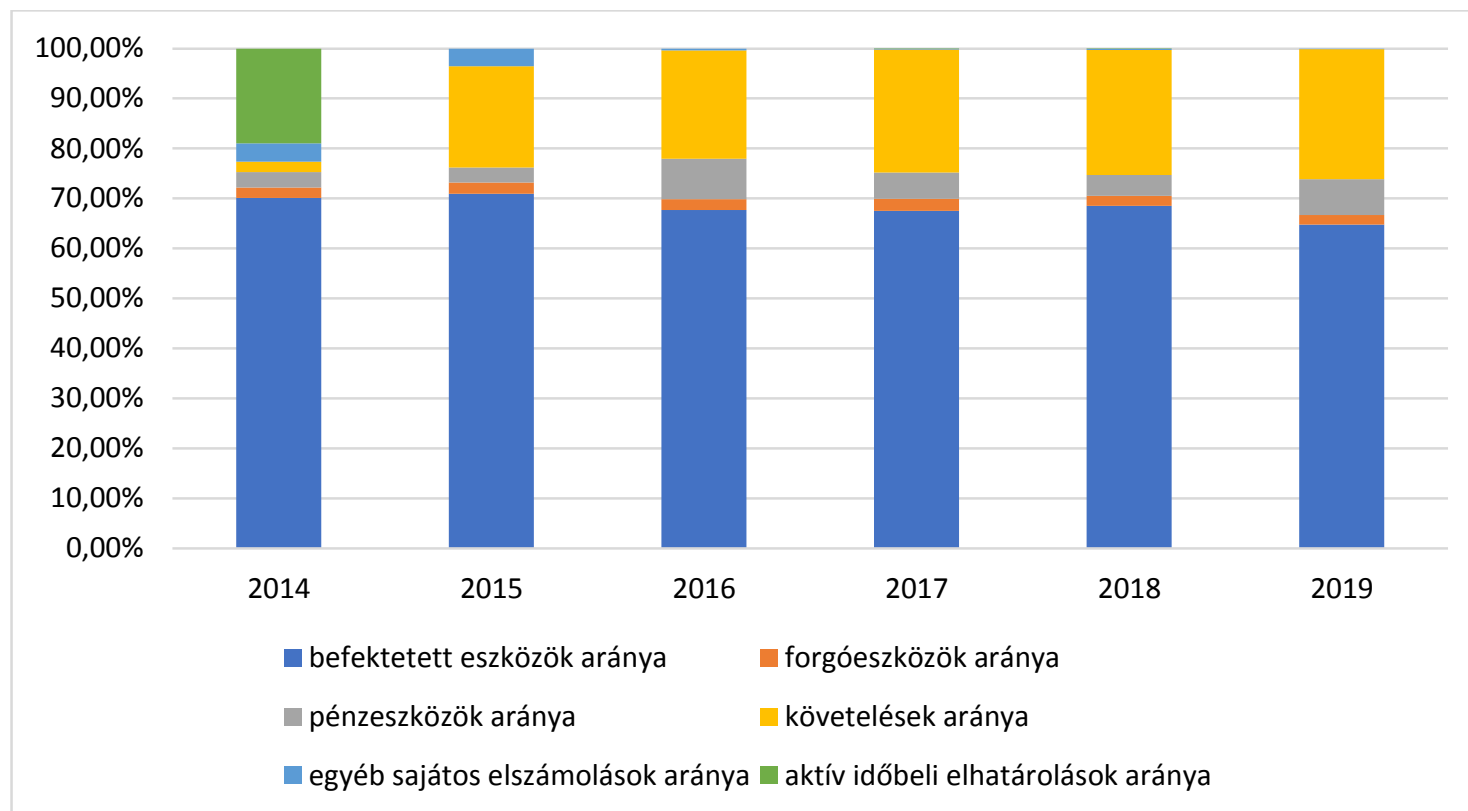

\section{2. ábra. Péterfy Sándor utcai Kórház-Rendelőintézet és Baleseti Központ eszközeinek megoszlása}

Az eszközök aránymutatóit vizsgálva az érzékelhető, hogy a vizsgált éveket figyelembe véve az intézmény eszközeinek körülbelül 70\%-a befektetett eszközök kategóriába tartozik, a forgóeszköz állomány tekintetében 2017. év óta enyhe csökkenés figyelhető meg, azaz a kórház a gyógyításhoz szükséges készletek tekintetében csak minimális eszközöket tart december 31-én a raktárába. Pénzeszközei szintén minimálisra csökkentettek, viszont 2018. évről 2019. évre jelentősen megemelkedett arányuk az eszközökön belül, de ez sem teszi ki az eszközök jelentős részét továbbra sem. 
Az egyéb sajátos eszközoldali elszámolásoknak záró értéke 19236 E Ft volt 2019. évben. A mérlegben ezen a jogcímen kerültek kimutatásra a december havi illetmények, munkabérek, illetve utalványok, bérletek elszámolásai. Itt egy kis korrekcióra volt szükség az össze-hasonlíthatóság és a legfrissebb mérleg séma használata miatt, a jelen tanulmányban E/III/1 mérlegsoron kerültek kimutatásra, azonban 2014-2015. években E/I mérlegsoron szerepelnek, viszont a tartalmuk ugyanaz, így átsorolás történt a mérleg eszközoldali sémájában, de tartalmilag ugyanazt az eredményt kapjuk mindkét tekintetben. Ezen jogcímeken feltüntetett érték az összes eszköz 3,66\%-a 2014. évben, 3,53\%-a 2015-ben, 0,37\%-a 2016-ban, 0,18\%-a 2017-ben, 0,24\%-a 2018. évben, a 2019. évben pedig $0,16 \%$-os értékkel bír.

\section{A mérlegben szereplö források vizsgálata}

\section{2. táblázat. A Péterfy Kórház-Rendelőintézet és Manninger Jenő Országos} Traumatológiai Intézet eszközeinek összehasonlítása

\begin{tabular}{|c|c|c|c|c|c|c|}
\hline Megnevezés & 2014 & 2015 & 2016 & 2017 & 2018 & 2019 \\
\hline G/I Nemzeti vagyon induláskori értéke & 13742683 & 13742683 & 13742683 & 13742683 & 13742683 & 13742683 \\
\hline G/II Nemzeti vagyon változásai & -24653 & -24653 & -24653 & -24653 & -24653 & -24653 \\
\hline G/IV Felhalmozott eredmény & -9436984 & -8785666 & -7746307 & -6798530 & -6963519 & -7348114 \\
\hline G/VI Mérleg szerinti eredmény & 245084 & 1039359 & 947777 & -164989 & -384595 & -2035659 \\
\hline G/ SAJÁT TÖKE & 4526130 & 5971723 & 6919500 & 6754511 & 6369916 & 4334258 \\
\hline $\begin{array}{l}\text { H/I/3 Költségvetési évben esedékes köte- } \\
\text { lezettségek dologi kiadásokra }\end{array}$ & 4205294 & 2819950 & 1752055 & 2076224 & 2461059 & 593508 \\
\hline $\begin{array}{l}\text { H/I/6 Költségvetési évben esedékes köte- } \\
\text { lezettségek beruházásokra }\end{array}$ & 19264 & 31112 & 10711 & 60828 & 32598 & - \\
\hline $\begin{array}{l}\text { H/I/7 Költségvetési évben esedékes köte- } \\
\text { lezettségek felújításokra }\end{array}$ & 1165 & - & 1232 & 60717 & 40033 & - \\
\hline $\begin{array}{l}\text { H/I Költségvetési évben esedékes kötele- } \\
\text { zettségek }\end{array}$ & 4225723 & 2851062 & 1763998 & 2197768 & 2533690 & 593509 \\
\hline $\begin{array}{l}\text { H/II/3 Költségvetési évet követően esedé- } \\
\text { kes kötelezettségek dologi kiadásokra }\end{array}$ & 348939 & 102 & - & 217606 & 93084 & 4723240 \\
\hline $\begin{array}{l}\text { H/II/6 Költségvetési évet követően esedé- } \\
\text { kes kötelezettségek beruházásokra }\end{array}$ & - & - & - & - & - & 57281 \\
\hline $\begin{array}{l}\text { H/II/7 Költségvetési évet követően esedé- } \\
\text { kes kötelezettségek felújításokra }\end{array}$ & - & - & - & - & - & 49925 \\
\hline $\begin{array}{l}\text { H/II/9 Költségvetési évet követően esedé- } \\
\text { kes kötelezettségek finanszírozási kiadá- } \\
\text { sokra }\end{array}$ & 406234 & 409714 & 432092 & 16903 & 27473 & 50268 \\
\hline $\begin{array}{l}\text { H/II Költségvetési évet követően esedékes } \\
\text { kötelezettségek }\end{array}$ & 755173 & 409816 & 432092 & 234509 & 120557 & 4880714 \\
\hline H/III/1 Kapott előlegek & 15313 & - & 1899 & 29 & 29 & 91 \\
\hline $\begin{array}{l}\text { H/III/3 Más szervezetet megillető bevéte- } \\
\text { lek elszámolása }\end{array}$ & - & 306 & - & - & - & - \\
\hline $\begin{array}{l}\text { H/III/8 Letétre, megőrzésre, fedezetkeze- } \\
\text { lésre átvett pénzeszközök, biztosítékok }\end{array}$ & 2133 & 2813 & 3210 & 3727 & 5393 & 4808 \\
\hline $\begin{array}{l}\text { H/III Kötelezettség jellegű sajátos elszá- } \\
\text { molások }\end{array}$ & 17446 & 3119 & 5109 & 3756 & 5422 & 4899 \\
\hline H) KÖTELEZETTSÉGEK & 4998342 & 3263997 & 2201199 & 2436033 & 2659669 & 5479122 \\
\hline $\begin{array}{l}\text { J/1 Eredményszemléletü bevételek passzív } \\
\text { időbeli elhatárolása }\end{array}$ & - & - & - & - & 65923 & - \\
\hline $\begin{array}{l}\text { J/2 Költségek, ráfordítások passzív időbeli } \\
\text { elhatárolása }\end{array}$ & 766445 & 719429 & 791567 & 882172 & 998697 & 1131448 \\
\hline $\begin{array}{l}\text { J/3 Halasztott eredményszemléletủ bevéte- } \\
\text { lek }\end{array}$ & 12520 & 365480 & 710119 & 847701 & 922972 & 890214 \\
\hline
\end{tabular}




\begin{tabular}{|l|r|r|r|r|r|r|}
\hline \multicolumn{1}{|c|}{ Megnevezés } & \multicolumn{1}{c|}{2014} & \multicolumn{1}{c|}{2015} & 2016 & \multicolumn{1}{c|}{2017} & \multicolumn{1}{c|}{2018} & 2019 \\
\hline $\begin{array}{l}\text { J) PASSZIV IDOBELI ELHATAROLA- } \\
\text { SOK }\end{array}$ & 778965 & 1084909 & 1501686 & 1729873 & 1987593 & 2021662 \\
\hline FORRÁSOK ÖSSZESEN & 10303437 & 10320629 & 10622385 & 10920418 & 11017177 & 11835042 \\
\hline
\end{tabular}

\section{Saját töke elemzése}

A forrásokon belül növekedett a saját tőke részaránya 2014-ben 43,93\%, majd 2015. évre 57,86\%ra, 2016. évre 65,14\%-ra nőtt, majd 2017-ben 61,85\%-ra csökkent, elsődlegesen a kötelezettségek arányának növekedése miatt, majd 57,82\%-ra csökkent 2018. évben, majd 2019. évre 36,62\%-ra tovább esett a mértéke.

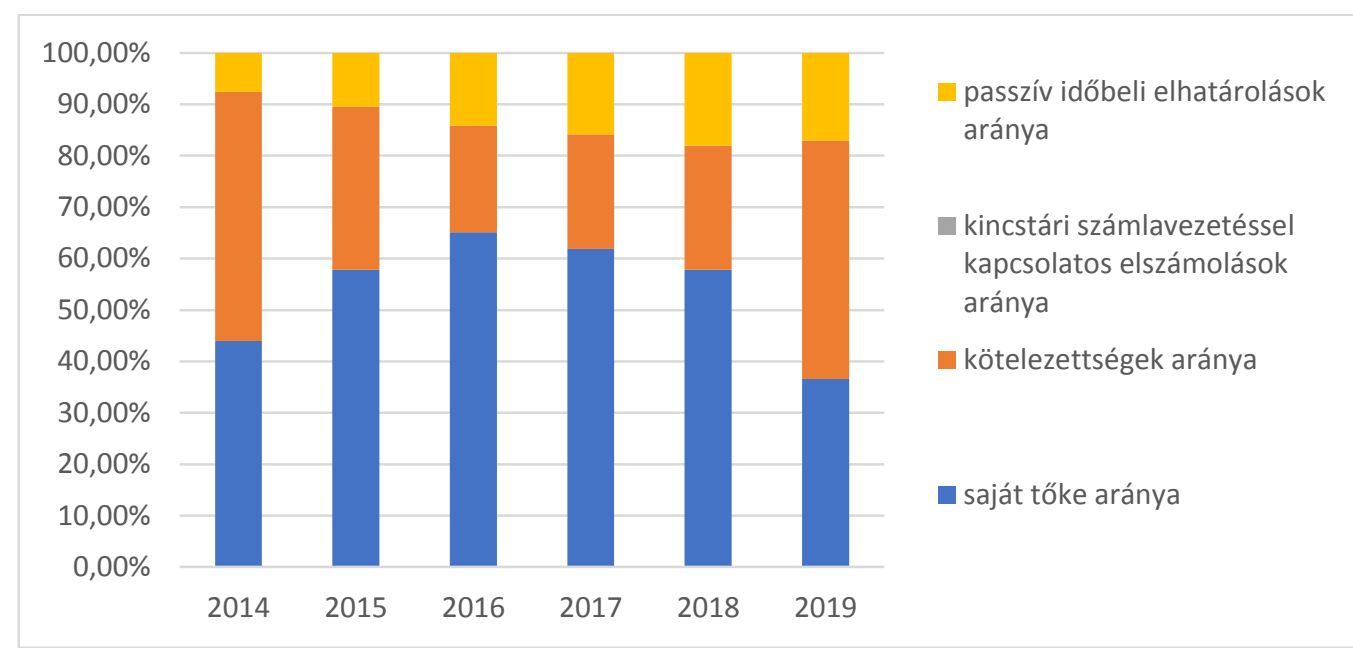

3. ábra. Péterfy Sándor utcai Kórház-Rendelőintézet és Baleseti Központ forrásainak megoszlása

3. táblázat. A Péterfy Kórház-Rendelőintézet és Manninger Jenő Országos Traumatológiai Intézet tőkeerősség és kötelezettségek részaránya mutató változása

\begin{tabular}{|l|c|c|c|c|c|c|}
\hline \multicolumn{1}{|c|}{ Megnevezés } & $\mathbf{2 0 1 4}$ & $\mathbf{2 0 1 5}$ & $\mathbf{2 0 1 6}$ & $\mathbf{2 0 1 7}$ & $\mathbf{2 0 1 8}$ & $\mathbf{2 0 1 9}$ \\
\hline tőkeerősség (saját tőke aránya) & $43,93 \%$ & $57,86 \%$ & $65,14 \%$ & $61,85 \%$ & $57,82 \%$ & $36,62 \%$ \\
\hline kötelezettségek aránya & $48,51 \%$ & $31,63 \%$ & $20,72 \%$ & $22,31 \%$ & $24,14 \%$ & $46,30 \%$ \\
\hline
\end{tabular}

\section{Kötelezettségek értékének alakulása}

Részarány tekintetében az összes kötelezettség forrásokhoz viszonyított aránya 2014. évben 48,51\% volt, majd 2015. évre 31,63\%-ra csökkent, 2016. évre tovább csökkent 20,72\%-ra, majd erről 22,31\%-ra nőtt a 2017. évre, majd a 2018. évre tovább növekedett és elérte a 24,14\%-os szintet, majd a tárgyévre a növekedés folytatódott és a mutató 46,30\%-os értékkel bírt 2019. évben. 


\section{Passzív időbeli elhatárolások vizsgálata}

A passzív időbeli elhatárolások 2019. évi összesen nyitó értéke 1987593 E Ft, a záró értéke 2021662 E Ft, mely 1,71\%-os növekedést jelent az előző időszakhoz, 2018. évhez képest. A paszszív időbeli elhatárolások forrásokon belüli részaránya 2014. évtől 2018-ig folyamatosan növekedett (7,56\%,10,51\%,14,14\%, 15,84\%, majd 18,04\% volt). 2019. évre részarány tekintetében egy enyhe csökkenés volt megfigyelhető, a korábbi, 2018. évi 18,04\%-ról 17,08\%-ra csökkent az értéke.

\section{Likviditási helyzet értékelése}

Az alanyi likviditás elemzése során azt vizsgáljuk a vállalkozás rendelkezik-e annyi mobil, vagy könnyen mobilizálható eszközértékkel, amennyi az esetleges kötelezettség teljesítéséhez szükséges. Az alanyi (relatív) likviditás hazai banki gyakorlat szerinti elfogadható értékének az 1,3-nél magasabb érték tekinthető. (Pataki, 2003)

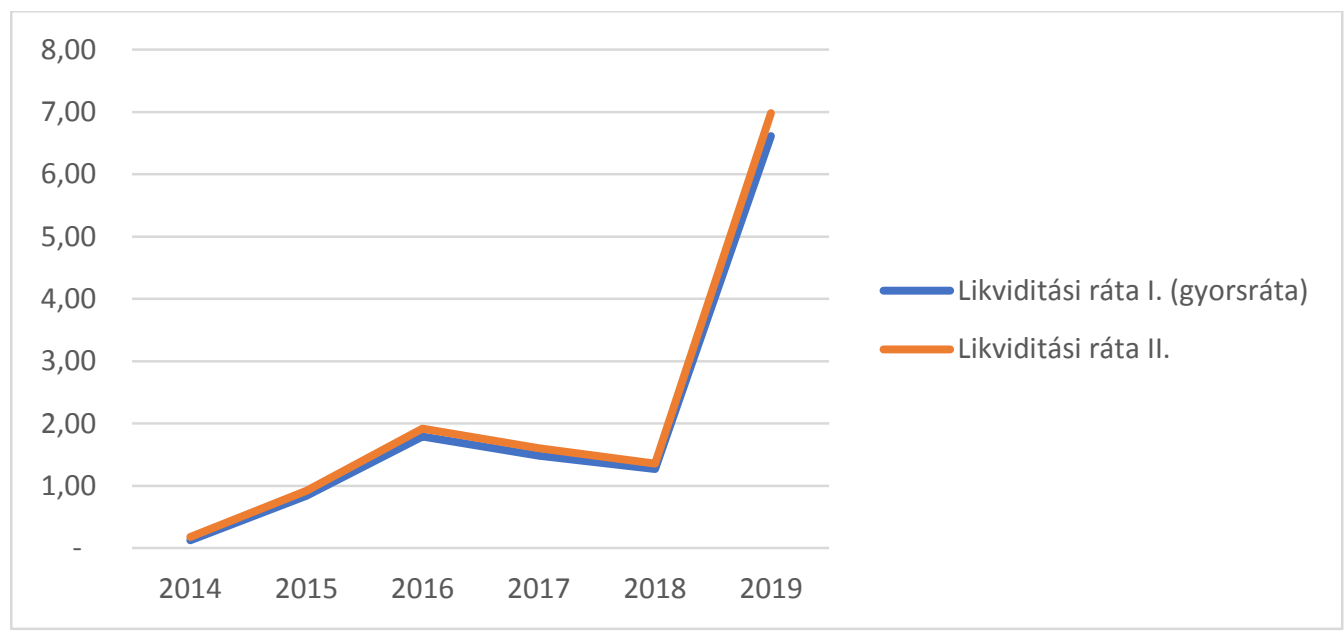

\section{4. ábra. A Péterfy Kórház-Rendelőintézet és Manninger Jenő Országos Traumatológiai Intézet likviditási mutatóinak változása (2014-2019)}

A likviditási gyorsráta (másodfokú likviditás) nem számol a forgóeszközök között szereplő készletekkel, amelyekkel a fizetések időpontjára gyakran nem tehetôk pénzzé.

A mutató együttható formában fejezi ki, hogy a készletekkel csökkentett likvid eszközök értéke hányszorosa az éven beül lejáratú idegen forrásnak.

A likviditási gyorsráta és a forgótőke aránymutatók rendkívül kedvezőtlenek voltak 2015. évig, és azt mutatták, hogy az Intézmény rövidtávon sem tudja finanszírozni kötelezettségeit, majd javulásnak indult. 2019. évben rendkívül jó értékekkel bírt az Intézmény a likviditási mutatókat tekintve.

\section{Forgótöke aránya}

A forgótőke aránya mutatja a saját forrással finanszírozott forgóeszközök értékét, azaz a saját források milyen mértékben fedezik a kötelezettség nélküli forgóeszközöket. 


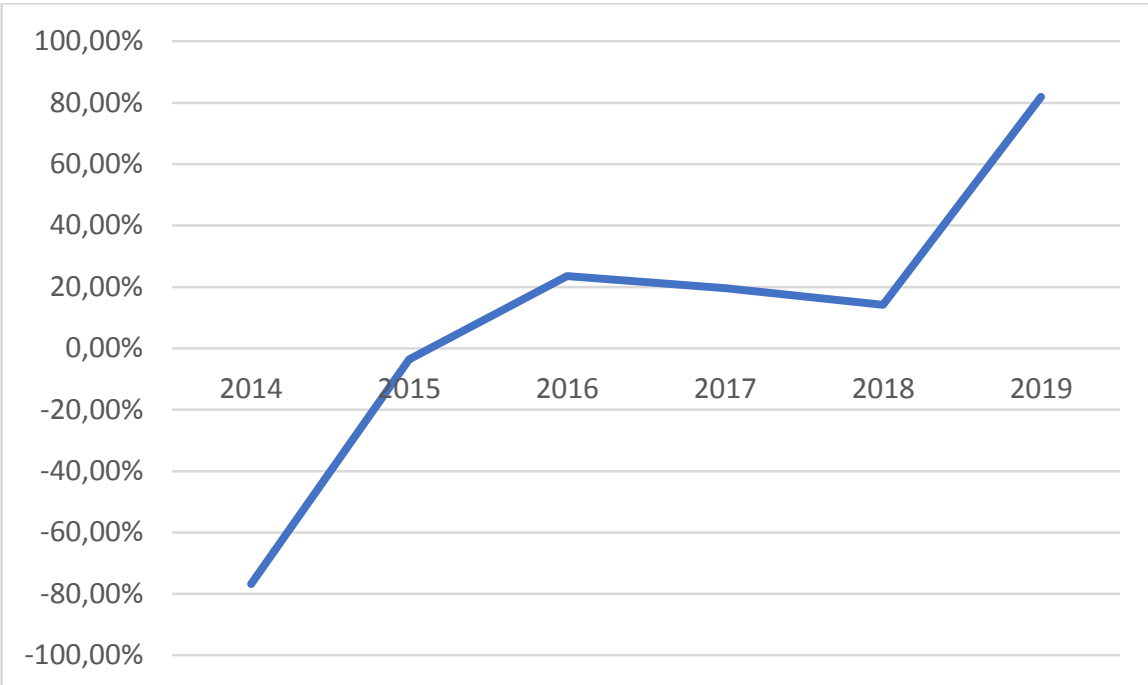

5. ábra. A Péterfy Kórház-Rendelőintézet és Manninger Jenő Országos Traumatológiai Intézet forgótőke arányának változása

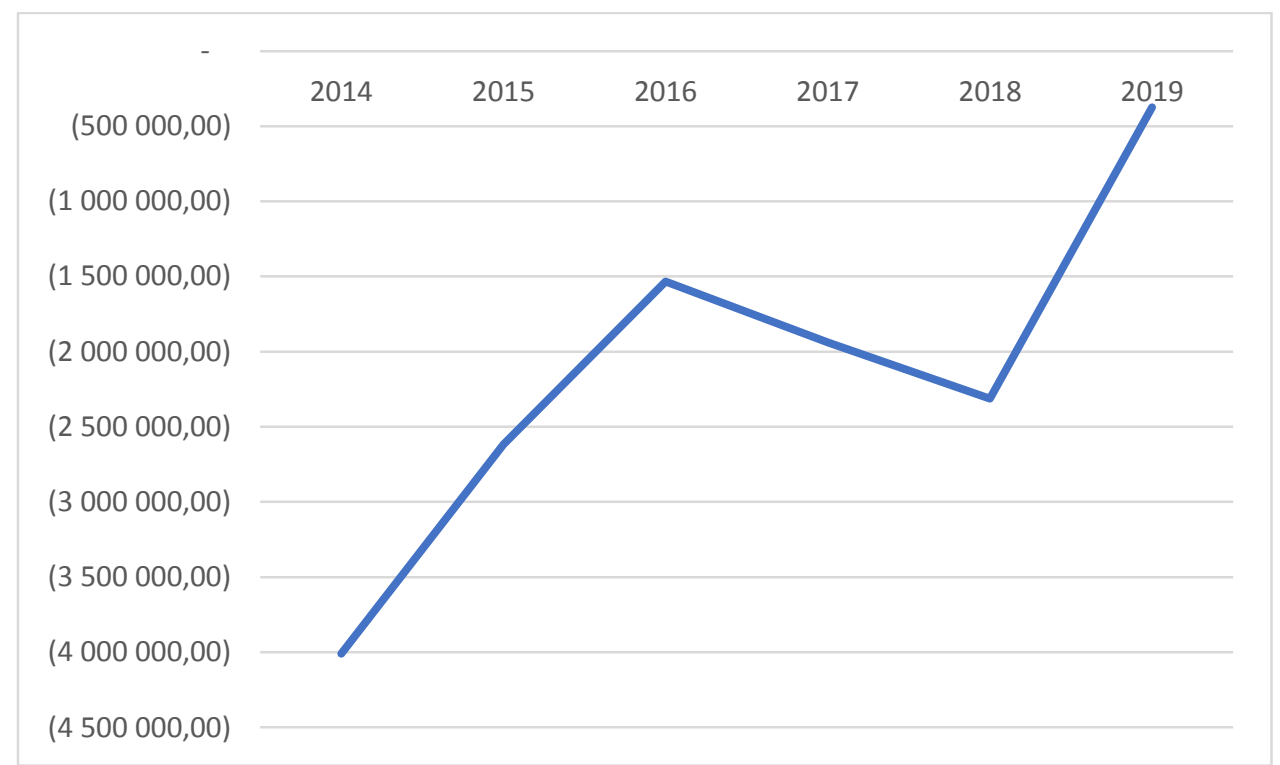

\section{6. ábra. A Péterfy Kórház-Rendelőintézet és Manninger Jenő Országos Traumatológiai Intézet nettó forgótőke változása}

A nettó forgótőke a folyó eszközök és a folyó kötelezettségek különbsége, tehát a forgóeszközök azon része, amely nem rövid lejáratú kötelezettségekkel van finanszírozva. Ha a nettó forgótôke negatív előjelû, akkor a forgóeszközök állományát meghaladja a rövid lejáratú kötelezettségek öszszege, így a tartós befektetések egy része is átmeneti forrásokkal van finanszírozva. (Szabó, 2008) Az egészségügyi intézmények nagy figyelmet kell fordítani erre a mutatószámra, mert a forrásai a Nemzeti Egészségbiztosítási Alapkezelőtől (NEAK, korábban OEP) származnak és ezenkívül más jelentős forrással nem rendelkeznek. Ha a nettó forgótőke negatív, akkor az intézmény nehéz helyzetben van, mert nem biztosított, hogy múködését folyamatosan fent tudná tartani. 
A Péterfy Kórház-Rendelőintézet és Manninger Jenő Országos Traumatológiai Intézet fentiekben elemzett 2014-2019. évi adatai alapján az mondható el, hogy az intézmény helyzete nehéz, alulfinanszírozottság jellemző rá, viszont a megfigyelt időszak alapján az mondható el, hogy 2019. évre jelentős javulás következett be.

Az Intézet helyzete javulni kezdett, a nettó forgótőke javulásnak indult, 2019. évben ugyan még negatív értékkel bír, de jelentősen jobb, mint a korábbi években volt.

\section{Csödmodell vizsgálat}

A válságkezelés leghatékonyabb módja a megelőzés, hiszen akkor nem tud kialakulni és nem a válságot kell megoldani, hanem előzetesen gondolkodni és tenni a megelőzésért. A folyamatos elemzések biztosítják, hogy alaposan megfontolt legyen a változtatási döntés. (Fazekas, 2007)

Ahhoz, hogy folyamatosan elemezzük egy társaság helyzetét korai figyelmeztető rendszerekre van szükség, amelyek előre jelzik, ha csőd veszélye merül fel.

A következőkben három csődmodellt részletezek, amelyek eredményessége igazolja, hogy előre jelezhetô a beszámolóadatok alapján, hogy hogyan alakul az adott társaság jövőbeni helyzete.

A Péterfy Kórház-Rendelőintézet és Manninger Jenő Országos Traumatológiai Intézet 20062019. évi beszámolóiból képzett mutatószámok alapján, illetve néhány a vállalkozási szférában alkalmazott csődmodellen keresztül került elemzésre.

\section{Comerford analízis}

A Comerford analízis hat mutatóból álló rendszer segítségével kíván előrejelzéseket készíteni adott vállalat, intézmény jövőbeni fizetőképességére, vagy fizetésképtelenségére vonatkozóan. A mutatószámrendszer a következőkből tevődik össze:

$$
\begin{array}{r}
x_{1}=\frac{\text { nettó jövedelem }}{\text { befektetett eszközök }} \\
x_{2}=\frac{\text { kötelezettségek }}{\text { befektetett eszközök }} \\
x_{3}=\frac{\text { pénzeszközök }+ \text { követelések }}{\text { befektetett eszközök }} \\
x_{4(2006-2013)}=\frac{\text { forgóeszközök }}{\text { rövid lejárítú kötelezettségek }} \\
x_{4(2014-2019)}^{\text {nemzeti vagyonba tartozó forgóeszközök }+ \text { követelések }+ \text { pénzeszközök }} \\
\text { rövid lejárítú kötelezettségek }
\end{array}
$$

Az x 4 érték számítása során figyelembe kellett venni, hogy 2014. évtől a költségvetési beszámoló sémája változott. A 2006-2013. évek vonatkozásában a forgóeszközök mérlegsor magában foglalta a készleteket, követeléseket, értékpapírokat, pénzeszközöket, illetve az egyéb aktív pénzügyi elszámolásokat. 2014. évtől kezdődően a nemzeti vagyonba tartozó forgóeszközök között csak a készletek és értékpapírok kerülnek kimutatásra. A követelések és pénzeszközök külön mérlegsoron szerepelnek, így ennek megfelelően szükséges volt a likviditási gyorsráta képletének megváltoztatása is. 


$$
\begin{gathered}
x_{5}=\frac{\text { pénzeszközö } k+k \text { övetelések }}{\text { rövid lejáratú kötelezettségek }} \\
x_{6}=\frac{\text { nettó jövedelem }}{\text { jegyzett tőke }}
\end{gathered}
$$

A fentiekben számolt mutatókat a következő matematikai összefüggésbe helyettesítjük be:

$$
Z=1,44 * x_{1}-1,78 * x_{2}+6,06 * x_{3}+0,63 * x_{4}-2,56 * x_{5}+0,37 * x_{6}
$$

4. táblázat. Comerford analízis (2006-2012)

\begin{tabular}{|c|c|c|c|c|c|c|c|}
\hline & 2013 & 2014 & 2015 & 2016 & 2017 & 2018 & 2019 \\
\hline $\mathrm{x} 1$ & 0,0133 & 0,0339 & 0,1419 & 0,1318 & $-0,0224$ & $-0,0509$ & $-0,2654$ \\
\hline $\mathrm{x} 2$ & 0,4893 & 0,6923 & 0,4457 & 0,3060 & 0,3303 & 0,3522 & 0,7143 \\
\hline x3 & 0,0798 & 0,0735 & 0,3276 & 0,4390 & 0,4423 & 0,4253 & 0,5117 \\
\hline$x 4$ & 0,2632 & 0,1771 & 0,9234 & 1,9214 & 1,6023 & 1,3553 & 6,9839 \\
\hline$x 5$ & 0,1833 & 0,1256 & 0,8415 & 1,7903 & 1,4840 & 1,2677 & 6,6133 \\
\hline x6 & 0,0134 & 0,0178 & 0,0756 & 0,0690 & $-0,0120$ & $-0,0280$ & $-0,1481$ \\
\hline $\mathrm{Z}$ & $-0,6692$ & $-0,9430$ & $-0,1575$ & $-1,0609$ & $-0,7501$ & $-0,5381$ & $-11,2075$ \\
\hline
\end{tabular}

\begin{tabular}{|l|r|r|r|r|r|r|r|}
\hline & $\mathbf{2 0 0 6}$ & $\mathbf{2 0 0 7}$ & $\mathbf{2 0 0 8}$ & \multicolumn{1}{c|}{$\mathbf{2 0 0 9}$} & \multicolumn{1}{c|}{$\mathbf{2 0 1 0}$} & \multicolumn{1}{c|}{$\mathbf{2 0 1 1}$} & $\mathbf{2 0 1 2}$ \\
\hline $\mathbf{x} \mathbf{1}$ & 0,0744 & 0,0992 & 0,1158 & 0,0298 & 0,0457 & 0,0226 & 0,1085 \\
\hline $\mathbf{x} \mathbf{x}$ & 0,1363 & 0,1929 & 0,2280 & 0,3587 & 0,3134 & 0,3462 & 0,5331 \\
\hline $\mathbf{x}$ & 0,0633 & 0,0832 & 0,1127 & 0,0231 & 0,0526 & 0,0124 & 0,1752 \\
\hline $\mathbf{x} \mathbf{4}$ & 2,1775 & 1,6439 & 1,0345 & 0,3743 & 0,5417 & 0,3809 & 0,4371 \\
\hline $\mathbf{x} \mathbf{6}$ & 0,8551 & 0,6684 & 0,6177 & 0,0736 & 0,2048 & 0,0423 & 0,3668 \\
\hline $\mathbf{Z}$ & 0,4464 & 0,5830 & 1,1216 & 0,2893 & 0,4271 & 0,2125 & 0,1111 \\
\hline
\end{tabular}

\section{5. táblázat. Comerford analízis (2013-2019)}

A módszer kritikus értéke $Z=0$. Minél inkább negatív irányba tér el a vállalati adatokból számolt Z érték, annál biztosabb az esély a bukásra, illetve minél inkább pozitív, annál nagyobb az esély az életben maradásra. (Fazekas, 2007)

Az analízis minden érintett évben csődöt jelez az intézménynél és az érték az utolsó vizsgált évre, a 2019. évre mutatja a legrosszabb helyzetet.

\section{Virág Miklós féle modell}

A modell négy mutatóból álló rendszer segítségével kíván előrejelzéseket készíteni adott vállalat jövőbeni fizetőképességére vagy fizetésképtelenségére vonatkozóan. A mutatószámrendszer a következőkből tevődik össze:

$$
\begin{aligned}
& \qquad x_{1}=\text { likviditási gyorsráta } \\
& \text { likviditási gyorsráta } a_{2006-2013}=\frac{\text { forgóeszközök-készletek }}{\text { rövid lejáratú kötelezettségek }}
\end{aligned}
$$

likviditási gyorsráta $a_{2014-2019}$

$$
=\frac{\text { nemzeti vagyonba tartozó forgóeszközö } k-k \text { észletek }+ \text { követelések }+ \text { pénzeszközök }}{\text { rövid lejáratú kötelezettségek }}
$$


Az $x_{1}$ érték számítása során figyelembe kellett venni, hogy 2014. évtől a költségvetési beszámoló sémája változott. A 2006-2013. évek vonatkozásában a forgóeszközök mérlegsor magában foglalta a készleteket, követeléseket, értékpapírokat, pénzeszközöket, illetve az egyéb aktív pénzügyi elszámolásokat. 2014. évtől kezdődően a nemzeti vagyonba tartozó forgóeszközök között csak a készletek és értékpapírok kerülnek kimutatásra. A követelések és pénzeszközök külön mérlegsoron szerepelnek, így ennek megfelelően szükséges volt a likviditási gyorsráta képletének megváltoztatása is.

$$
\begin{aligned}
& x_{2}=\frac{\text { pénzeszközök változása }}{k \text { ötelezettségek }} \\
& x_{3}=\frac{\text { forgóeszközö } k}{\text { eszközö } k}
\end{aligned}
$$

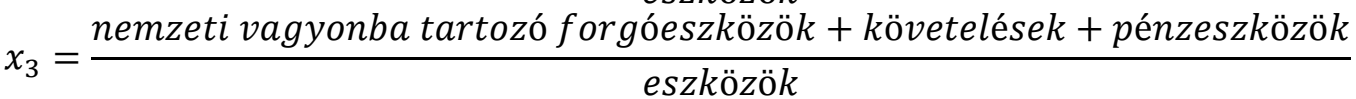

Az összehasonlíthatóság biztosítása miatt az x3 érték számolása esetében is figyelembe kellett venni a mérlegséma változást és ez alapján a 2014-2019. évekre vonatkozóan a képletet aktualizálni.

$$
x_{4}=\frac{\text { pénzeszközök változása }}{e s z k o ̈ z o ̈ k}
$$

A fentiekben számolt mutatókat a következő matematikai összefüggésbe helyettesítjük be:

\begin{tabular}{|c|c|c|c|c|c|c|c|}
\hline & 2006 & 2007 & 2008 & 2009 & 2010 & 2011 & 2012 \\
\hline $\mathrm{x} 1$ & 1,8556 & 1,3958 & 0,9141 & 0,2633 & 0,4404 & 0,2845 & 0,3728 \\
\hline $\mathrm{x} 2$ & $-0,0955$ & 0,0234 & 0,2780 & $-0,2505$ & 0,0799 & $-0,1081$ & 0,3021 \\
\hline x3 & 0,1389 & 0,1699 & 0,1588 & 0,1050 & 0,1222 & 0,1006 & 0,1727 \\
\hline $\mathrm{x} 4$ & $-0,0112$ & 0,0037 & 0,0533 & $-0,0804$ & 0,0220 & $-0,0337$ & 0,1333 \\
\hline csőd & $-3,3675$ & $-4,5748$ & $-5,5124$ & $-7,3559$ & $-6,9169$ & $-7,3853$ & $-6,8955$ \\
\hline kontroll & $-1,9538$ & $-3,7297$ & $-5,0124$ & $-9,5426$ & $-8,0786$ & $-9,3673$ & $-7,3773$ \\
\hline $\mathrm{Z}$ & 2,8697 & 2,5543 & 2,2781 & 0,3296 & 1,1766 & 0,5768 & 1,6366 \\
\hline
\end{tabular}

$$
Z=1,3566 * x_{1}+1,63397 * x_{2}+3,66384 * x_{3}+0,03366 * x_{4}
$$

6. táblázat. Virág Miklós féle modell (2006-2012)

7. táblázat. Virág Miklós féle modell (2013-2019)

\begin{tabular}{|l|r|r|r|r|r|r|r|}
\hline & $\mathbf{2 0 1 3}$ & \multicolumn{1}{c|}{$\mathbf{2 0 1 4}$} & \multicolumn{1}{c|}{$\mathbf{2 0 1 5}$} & \multicolumn{1}{c|}{$\mathbf{2 0 1 6}$} & \multicolumn{1}{c|}{$\mathbf{2 0 1 7}$} & \multicolumn{1}{c|}{$\mathbf{2 0 1 8}$} & $\mathbf{2 0 1 9}$ \\
\hline $\mathbf{x} \mathbf{x}$ & 0,1911 & 0,1256 & 0,8415 & 1,7903 & 1,4840 & 1,2677 & 6,6133 \\
\hline $\mathbf{2}$ & $-0,2034$ & $-0,0381$ & $-0,0031$ & 0,2478 & $-0,1148$ & $-0,0462$ & 0,0733 \\
\hline $\mathbf{x} \mathbf{4}$ & 0,1028 & 0,0726 & 0,2551 & 0,3191 & 0,3225 & 0,3117 & 0,3502 \\
\hline csőd & $-0,0893$ & $-0,0185$ & $-0,0010$ & 0,0513 & $-0,0256$ & $-0,0111$ & 0,0339 \\
\hline kontrol1 & $-7,2990$ & $-7,6798$ & $-6,8697$ & $-5,4283$ & $-5,8985$ & $-6,2584$ & 2,8372 \\
\hline $\mathbf{Z}$ & $-9,3657$ & $-9,9222$ & $-7,4147$ & $-4,0400$ & $-5,5083$ & $-6,0886$ & 10,5971 \\
\hline
\end{tabular}


A kritikus Z érték 2,61612, tehát ha az adott vállalat megfelelő pénzügyi mutatóit a függvénybe helyettesítve 2,61612-nél nagyobb számot kapunk, akkor a függvény a céget fizetőképesnek, egyébként pedig fizetésképtelennek minősíti. (Virág-Kristóf, 2005)

Az elemzés a vizsgált évek többségében fizetésképtelennek minősíti az intézményt és az érték évről évre kedvezőtlen helyzetet jelez a 2006-2015. évek vonatkozásában, viszont 2016. óta stabilan fizetőképesnek mutatják a számok az Intézményt. A Virág Miklós féle modell, tehát teljesen ellentétes eredményt mutat, mint az előbbiekben bemutatott Comerford analízis.

\section{A kanonikus diszkriminancia - Ékes féle modell}

A kanonikus diszkriminancia (Z) függvény értéke:

$$
Z=2,121-0,104 * D_{1}-1,102 * D_{2}+0,238 * D_{3}+0,497 * D_{4}-0,146 * x_{4}
$$

ahol

$$
\begin{aligned}
& D_{1}=\frac{\text { forgóeszközök }}{\text { eszközö } k} \\
& D_{1}=\frac{\text { nemzeti vagyonba tartozó forgóeszközö } k+k \text { övetelése } k+\text { pénzeszközö } k}{e s z k \text { özö } k}
\end{aligned}
$$

Az összehasonlíthatóság biztosítása miatt a D1 érték képlet aktualizálása is szükségessé vált a mérlegséma változás okán a 2014-2019. évekre vonatkozóan.

$$
\begin{gathered}
D_{2}=\frac{\text { vevő } i \text { követelések }}{\text { eszközök }} \\
D_{3}=\frac{\text { saját tőke }}{\text { befektetett eszközök }} \\
D_{4}=\frac{\text { saját tőke }}{\text { források }} \\
x_{4}=\frac{\text { saját tôke piaci értéke }}{\text { összes adósság könyv szerinti értéke }}
\end{gathered}
$$

8. táblázat. A kanonikus diszkriminancia - Ékes féle modell (2006-2012)

\begin{tabular}{|l|r|r|r|r|r|r|r|}
\hline & $\mathbf{2 0 0 6}$ & $\mathbf{2 0 0 7}$ & \multicolumn{1}{c|}{$\mathbf{2 0 0 8}$} & \multicolumn{1}{c|}{$\mathbf{2 0 0 9}$} & \multicolumn{1}{|c|}{$\mathbf{2 0 1 0}$} & \multicolumn{1}{c|}{$\mathbf{2 0 1 1}$} & $\mathbf{2 0 1 2}$ \\
\hline $\mathbf{D 1}$ & 0,1389 & 0,1699 & 0,1588 & 0,1050 & 0,1222 & 0,1006 & 0,1727 \\
\hline $\mathbf{D} 2$ & 0,0093 & 0,0098 & 0,0049 & 0,0054 & 0,0087 & 0,0066 & 0,0073 \\
\hline $\mathbf{D} 3$ & 0,9505 & 0,9125 & 0,8451 & 0,7287 & 0,7802 & 0,7431 & 0,5671 \\
\hline D4 & 0,8185 & 0,7575 & 0,7108 & 0,6523 & 0,6848 & 0,6683 & 0,4691 \\
\hline $\mathbf{X} 4$ & $\mathbf{6 , 9 7 2 2}$ & $\mathbf{4 , 7 3 1 3}$ & 3,7066 & 2,0317 & 2,4893 & 2,1467 & 1,0636 \\
\hline $\mathbf{Z}$ & $\mathbf{1 , 7 1 1 4}$ & $\mathbf{1 , 9 9 5 4}$ & $\mathbf{2 , 1 1 2 3}$ & $\mathbf{2 , 3 0 5 1}$ & $\mathbf{2 , 2 6 1 3}$ & $\mathbf{2 , 2 9 8 9}$ & $\mathbf{2 , 3 0 7 9}$ \\
\hline
\end{tabular}


9. táblázat. A kanonikus diszkriminancia - Ékes féle modell (2012-2019)

\begin{tabular}{|l|r|r|r|r|r|r|r|}
\hline & $\mathbf{2 0 1 3}$ & $\mathbf{2 0 1 4}$ & $\mathbf{2 0 1 5}$ & $\mathbf{2 0 1 6}$ & $\mathbf{2 0 1 7}$ & \multicolumn{1}{c|}{$\mathbf{2 0 1 8}$} & $\mathbf{2 0 1 9}$ \\
\hline $\mathbf{D 1}$ & 0,1028 & 0,0726 & 0,2551 & 0,3191 & 0,3225 & 0,3117 & 0,3502 \\
\hline $\mathbf{D} 2$ & 0,0092 & 0,0107 & 0,0088 & 0,2013 & 0,0108 & 0,0149 & 0,0162 \\
\hline $\mathbf{D 3}$ & 0,6120 & 0,6269 & 0,8154 & 0,9619 & 0,9159 & 0,8435 & 0,5650 \\
\hline $\mathbf{D} 4$ & 0,5491 & 0,4393 & 0,5786 & 0,6514 & 0,6185 & 0,5782 & 0,3662 \\
\hline $\mathbf{X} 4$ & 1,2508 & 0,9055 & 1,8296 & 3,1435 & 2,7728 & 2,3950 & 0,7910 \\
\hline $\mathbf{Z}$ & $\mathbf{2 , 3 3 6 1}$ & $\mathbf{2 , 3 3 7 0}$ & $\mathbf{2 , 2 9 9 3}$ & $\mathbf{1 , 9 5 9 7}$ & $\mathbf{2 , 1 9 6 1}$ & $\mathbf{2 , 2 1 0 6}$ & $\mathbf{2 , 2 6 7 7}$ \\
\hline
\end{tabular}

A csoportba sorolás határértéke $Z=0$. A nullánál kisebb érték a „csőd-csoportba” tartozást jelzi. (Ékes, 2013) Az elemzés e modul szerint nem jelzi a csődveszélyt.

\section{Köveztetések és javaslatok}

Elemzésünk során részletesebben megvizsgáltuk az 3 féle csődelőrejelző modell egészségügyi szolgáltatók Az általunk vizsgált ágazatban a következtetésre arra jutottunk, hogy a modellek csak minimális mértékben képesek megfelelően előre jelezni sem a csőd közeli állapotot.

A három csődanalízisből kettő egyértelműen a fizetésképesség helyzetét mutatja az intézménynél, azt mondhatjuk, hogy statisztikai elemzéssel is alátámasztott a kórház esetében, hogy likviditási problémája nincs. A vizsgálatot nagymértékben befolyásolta, hogy a vizsgált intézmények az adott tárgyévben a lejárt szállítói tartozásuk kiegyenlítésére jelentős mértékủ konszolidációs támogatást kaptak.

Kutatásunk további részében SPSS statisztikai szoftver használatával próbáltunk a változók közötti összefüggésekre rámutatni és esetleges kapcsolatot találni. A varianciaanalízis nem mutatott ki kapcsolatot a csődbejutás jelensége és a pénzügyi típusjelenségek között.

\section{Hivatkozott források}

[1.] Ékes SZ. K. (2013): A vállalati szeletor csódelórejelzésének „relativitás elmélete”. E-Conom Online Tudományos Folyóirat. Tanulmányok a gazdaság- és társadalomtudományok területérôl. II/2. Letöltés dátuma: 2020.11.09. forrás: http://real.mtak.hu/30153/1/11 EkesSzK e conom II2 u.pdf

[2.] Fazekas B. (2007): Vállalati változ̧tatás és válságmenedzsment és alkalmazott pénzüigyi módszerek. Gödöllő. [Diplomamunka] 35-36. Letöltés dátuma: 2020.11.09. forrás: https:// docplayer.hu/1028870-Vallalati-valtoztatas-es-valsagmenedzsment-es-alkalmazottpenzugyi-modszerek.html

[3.] Pataki L. (2003): Pénzü̈gyi alapismeretek. Távoktatási jegyzet. Gyöngyös: Szent István Egyetem Gazdálkodási és Mezőgazdasági Főiskolai Kar.

[4.] Szabó M. (2008): Alkalmazott gazdaságtan - pénzügyi elemzések. Nemzeti Szakképzési és Felnőttképzési Intézet. Budapest. Letöltés dátuma: 2020.11.09. forrás: 
https://www.nive.hu/Downloads/Szakkepzesi dokumentumok/Bemeneti kompetenciak meresi ertekelesi eszkozrendszerenek kialakitasa/7 1155013100915. pdf

[5.] Virág M., Kristóf T. (2005): Az első hazai csődmodell újraszámítása neurális hálók segítségével. Körgazdasági sz̧emle. 52. (2) 147.-148. Letöltés dátuma: 2020.11.09. forrás: http://unipub.lib.uni-corvinus.hu/3465/1/Kszemle CIKK 744.pdf

\section{Szerző}

\section{Hegedûs Mihály}

ORCID: 0000-0001-8064-0208

$\mathrm{PhD}$

föiskolai tanár

Tomori Pál Főiskola

hegedus@hkaudit.hu 